\title{
PREFACE
}

\section{Celebrating limnology in Siberia: commemorating the 90th anniversary of the Limnological Institute in Irkutsk, Russia}

\author{
Marianne V. Moore ${ }^{1} \cdot$ Masumi Yamamuro $^{2}$ \\ Received: 15 November 2019 / Accepted: 24 November 2019 / Published online: 11 December 2019 \\ (C) The Japanese Society of Limnology 2019
}

September, 2018 marked the 90th anniversary of one of the longest functioning limnological research institutes in the world-the Limnological Institute (LIN) of the Siberian Branch of the Russian Academy of Sciences located in Irkutsk, Russia. Originating in 1928 as the Baikal Limnological Station on the southwest shore of Lake Baikal, the institute distinguished itself quickly for its remarkable productivity. Between 1928 and 1940, a period of great hardship for Soviet scientists, 250 papers were published by the institute's mere handful of scientists on such diverse topics as the hydrological regime of the Angara River (Lake Baikal's sole outlet), the biology of the lake's commercially important whitefish, and the coastal geomorphology of the lake. Today, this thriving institute, with a research fleet of 4 vessels and a research diving team, is the workplace of more than 130 freshwater scientists including biologists, chemists, physicists, and geologists who have collaborated with international scientists from 28 different countries between 2013 and 2018.

Recent key findings of LIN's scientists illustrate both the breadth of their research and the uniqueness of Lake Baikal. For example, LIN scientists, often with international colleagues, elucidated the drivers of Lake Baikal's enigmatic deep-water ventilation process (Wüest et al. 2005; Schmid et al. 2008), described coastal and pelagic upwelling events (Shimaraev et al. 2012; Troitskaya et al. 2015) and reconstructed paleoclimates for eastern Siberia using sediments

Handling Editor: Ichiro Tayasu.

Marianne V. Moore

mmoore@wellesley.edu

1 Department of Biological Sciences, Wellesley College, Wellesley, MA 01770, USA

2 Graduate School of Frontier Sciences, The University of Tokyo, Kashiwanoha, Kashiwa 277-8563, Japan extracted from local lakes (Stepanova et al. 2019) and the extraordinarily deep, $7 \mathrm{~km}$-thick layer comprising the floor of Lake Baikal (BDP-99 Drilling Project Members 2005). In addition, LIN scientists, since 2000, have discovered more than 50 methane hydrate accumulations, previously thought to be restricted to marine habitats, on the bottom of Lake Baikal (Khlystov et al. 2018), and they described the world's only freshwater macroinvertebrate communities associated with the lake's hydrothermal vents and cold seeps (Zemskaya et al. 2012). Other unusual communities described by LIN scientists include the cryophilic community composed of phytoplankton, ciliates, and rotifers living in the lake's ice (Obolkina et al. 2000; Bondarenko et al. 2012) and the surprising diversity and abundance of organisms inhabiting the splash zone (Timoshkin 2018), a habitat that has received almost no attention in other lakes. Of course, Lake Baikal's many endemic species and its 25 million year history make it an ideal natural laboratory for pursuing questions regarding the evolutionary origins and history of Lake Baikal's fauna with current work suggesting that many faunal groups have recently radiated rapidly (Sherbakov 1999; Stelbrink et al. 2015). Water chemistry research too has been central to LIN's research on Lake Baikal and the surrounding region, with recent work showing that nutrient concentrations have increased in the lake's littoral zone while concentrations offshore have remained stable (Khodzher et al. 2017, 2018). Sadly, anthropogenic nutrient loading from untreated sewage and contaminated groundwater has led recently to the massive growth of benthic algae in localized areas of Lake Baikal's coastal zone (Timoshkin et al. 2018), and the spectacular, endemic sponge forests of the littoral zone (Kozhova and Izmest' eva 1998) appear to be suffering from the action of opportunistic pathogens (Belikov et al. 2019).

Nearly all of the topics noted above and more were represented at the celebration of the institute's 90th birthday in 2018, which consisted of a stimulating five-day scientific 
conference, titled "Freshwater Ecosystems - Key Problems". At this conference, scientists from Russia, Japan, Europe, North America, and Africa presented papers focusing on fundamental and applied topics of limnology. Five of these papers, all addressing different aspects of biological limnology, are presented in this special issue of Limnology. Four of the papers use molecular biology techniques to explore aspects of biodiversity or phylogenetic relationships of organisms from L. Baikal (Kulakova et al. 2019; Naganawa et al. 2019; Protasov et al. 2019; Yakhnenko and Itskovich 2019) while the fifth paper describes trends in zoobenthic community structure in 49 lakes situated across three terrestrial biomes (steppe, forest-steppe, and taiga) in southwestern Siberia (Bezmaternykh and Vdovina 2019). Additional papers from the conference have been or will be published in Quaternary International, Journal of Great Lakes Research, Russian Journal of Ecology, and Geography and Natural Resources.

We hope the papers presented here and in the journals mentioned above will help stimulate future research on Siberian inland waters, and we thank each of the reviewers whose generous insights and helpful suggestions improved these papers.

\section{References}

BDP-99 Baikal Drilling Project Members (2005) A new Quaternary record of regional tectonic, sedimentation and paleoclimate changes from drill core BDP-99 at Posolskaya Bank Lake Baikal. Quat Int 136:105-121. https://doi.org/10.1016/j.quaint.2004.11.012

Belikov S, Belkova N, Butina T, Chernogor L, Martynova-Van Kley A, Nalian A, Rorex C, Khanaev I, Maikova O, Feranchuk S (2019) Diversity and shifts of the bacterial community associated with Baikal sponge mass mortalities. PLoS ONE 14:e0213926. https://doi. org/10.1371/journal.pone.0213926

Bezmaternykh DM, Vdovina ON (2019) Composition and structure of macrozoobenthos of lakes in different natural zones and subzones of Western Siberia. Limnology. https://doi.org/10.1007/s10201-01900586-y

Bondarenko NA, Belykh OI, Golobokova LP, Artemyeva OV, Logacheva NF, Tikhonova IV, Lipko IA, Kostornova TYa, Parfenova VV, Khodzher TV, Ahn T-S, Zo Y-G (2012) Stratified distribution of nutrients and extremophile biota within freshwater ice covering the surface of Lake Baikal. J. Microbiol 50:8-16. https://doi. org/10.1007/s12275-012-1251-1

Khodzher TV, Domysheva VM, Sorokovikova LM, Sakirko MV, Tomberg IV (2017) Current chemical composition of Lake Baikal water. Inland Waters 7:250-258. https://doi.org/10.1080/20442 041.2017.1329982

Khodzher TV, Domysheva VM, Sorokovikova LM, Tomberg IV, Sakirko MV (2018) Hydrochemical studies in Lake Baikal: history and nowadays. Limnol Freshw Biol 1:2-9. https://doi.org/10.31951 /2658-3518-2018-A-1-2

Khylstov OM, Khabuev AV, Minami H, Hachikubo A, Krylov AA (2018) Gas hydrates in Lake Baikal. Limnol Freshwat Biol 1:66-70. https ://doi.org/10.31951/2658-3518-2018-A-1-66

Kozhova OM, Izmest'eva LR (eds) (1998) Lake Baikal: evolution and biodiversity. Backhuys, Leiden
Kulakova NV, Kashin SA, Bukin YS (2019) Genetic diversity and phylogeny of the green microalgae Choricystis (Trebouxiophyceae, Chlorophyta) in Lake Baikal. Limnology. https://doi.org/10.1007/ s10201-019-00587-x

Naganawa H, Naumova EYu, Denikina NN, Kondratov IG, Dzyuba EV, Iwasawa A (2019) Does the dispersal of fairy shrimps (Branchiopoda, Anostraca) reflect the shifting geographical distribution of freshwaters since the late Mesozoic? Limnology. https://doi. org/10.1007/s10201-019-00589-9

Obolkina LA, Bondarenko NA, Doroshchenko LF, Gorbynova LA, Molozhavaya OA (2000) On finding of cryophilic community of Lake Baikal. Dokl Akad Nauk SSSR 371:815-817

Protasov ES, Axenov-Gribanov DV, Rzhechitsky YaA, Emshanova VA, Shirokova YA, Timofeyev MA (2019) Diversity of culturable actinobacteria associated with deepwater endemic amphipods of Lake Baikal and study of their biosynthetic capabilities. Limnology. https ://doi.org/10.1007/s10201-019-00593-Z

Schmid M, Budnev NM, Granin NG, Sturm M, Schurter M, Wüest A (2008) Lake Baikal deepwater renewal mystery solved. Geophys Res Lett 35:L09605. https://doi.org/10.1029/2008GL033223

Sherbakov DYu (1999) Molecular phylogenetic studies on the origin of biodiversity in Lake Baikal. Trends Ecol Evol 14:92-95

Shimaraev MN, Troitskaya ES, Blinov VV, Ivanov VG, Gnatovski RYu (2012) Upwellings in Lake Baikal. Dokl Earth Sci 442:272-276. https://doi.org/10.1134/S1028334X12020183

Stelbrink B, Shirokaya AA, Clewing C, Sitnikova TY, Prozorova LA, Albrecht C (2015) Conquest of the deep, old and cold: an exceptional limpet radiation in Lake Baikal. Biol Lett 11:20150321. https ://doi.org/10.1098/rsbl.2015.0321

Stepanova OG, Trunova VA, Osipov EYu, Kononov EE, Vorobyeva SS, Parkhomchuk EV, Kalinkin PN, Vorobyeva EE, Vershinin KE, Rastigeev SA, Fedotov AP (2019) Glacier dynamics in the southern part of East Siberia (Russia) from the final part of the LGM to the present based on biogeochemical proxies from bottom sediments of proglacial lakes. Quat Int 524:4-12. https://doi.org/10.1016/j.quain t.2019.03.003

Timoshkin OA (2018) Coastal zone of the world's great lakes as a target field for interdisciplinary research and ecosystem monitoring: Lake Baikal (East Siberia). J Limnol Freshw Biol 1:81-97. https://doi. org/10.31951/2658-3518-2018-A-1-81

Timoshkin OA, Moore MV, Kulikova NN, Tomberg IV, Malnik VV, Shimaraev MN, Troitskaya ES, Shirokaya AA, Sinyukovich VN, Zaitseva EP, Domysheva VM, Yamamuro M, Poberezhnaya AE, Timoshkina EM (2018) Groundwater contamination by sewage causes benthic algal outbreaks in the littoral zone of Lake Baikal (East Siberia). J Great Lakes Res 44:230-244. https://doi. org/10.1016/j.jglr.2018.01.008

Troitskaya E, Blinov V, Ivanov V, Zhdanov A, Gnatovsky R, Sutyrina E, Shimaraev M (2015) Cyclonic circulation and upwelling in Lake Baikal. Aquat Sci 77:171-182. https://doi.org/10.1007/s0002 7-014-0361-8

Wüest A, Ravens TM, Granin NG, Kocsis O, Schurter M, Sturm M (2005) Cold intrusions in Lake Baikal: direct observational evidence for deep-water renewal. Limnol Oceanogr 50:184-196. https://doi. org/10.4319/lo.2005.50.1.0184

Yakhnenko AS, Itskovich VB (2019) Analysis of mtDNA variability in closely related Baikal sponge for new barcoding marker development. Limnology. https://doi.org/10.1007/s10201-019-00599-7

Zemskaya TI, Sitnikova TY, Kiyashko SI, Kalmychkov GV, Pogodaeva TV, Mekhanikova IV, Naumova TV, Shubenkova OV, Chernitsina SM, Kotsar OV, Chernyaev ES, Khlystov OM (2012) Faunal communities at sites of gas-and oil-bearing fluids in Lake Baikal. Geo Mar Lett 32:437-451. https://doi.org/10.1007/s00367-012-0297-8

Publisher's Note Springer Nature remains neutral with regard to jurisdictional claims in published maps and institutional affiliations. 